\title{
Problems and Prospects of SME Financing in Bangladesh
}

\author{
Md. Shahnur Azad Chowdhury', Md Kazi Golam Azam², \& Serajul Islam³ \\ ${ }^{1}$ Assistant Professor, Department of Business Administration, International Islamic University Chittagong, Bangladesh \\ ${ }^{2}$ Lecturer, Department of Business Administration, International Islamic University Chittagong, Bangladesh \\ ${ }^{3}$ Associate Professor, Department of Business Administration, International Islamic University Chittagong, Bangladesh
}

\begin{abstract}
The present study is conducted to analyze the potential of SMEs in the economy of Bangladesh. Data were collected from $100 \mathrm{SME}$ units by using simple random technique. A structural questionnaire was developed to get the responses from different SME units in the country. For Bangladesh SMEs have assumed special significance for poverty reduction programmes and potential contribution to the overall industrial and economic growth. Some of the constraints related SME financing are identified and some pointers for the future are provided through the study.
\end{abstract}

Key words: SME, GDP, Economy

\section{INTRODUCTION}

B angladesh is an agricultural based country, where around $85 \%$ people are living at village with activities of agriculture, in this perspective Bangladesh can achieve industrialization through agriculture based small and cottage industry to start aggressively. Small and medium enterprises (SMEs) make up the largest portion of the employment base in many developing countries and, indeed, are often the foundation of the local private sector. Now the SMEs are not only concentrated to low-tech, traditional, and agro-based economic activities; these are spread over other non-traditional manufacturing and service sector as well. In fact, the SMEs are recognized as engines of economic growth worldwide. To achieve high and sustained economic growth, a triggering force is mandatory to exit from endemic poverty and socioeconomic deprivation. The entrepreneurs behind couldand should-play a much larger role in development, but too often are held back by a lack of ready access to financing from local formal sector financial institutions. Here lies the scope of commercial banks to offer banking facilities to this 'missing middle' by offering different products that are specially featured for this segment. On a long term perspective these commercial banks expect to gradually develop the creation of an entrepreneurial class across Bangladesh through proper financing and training. Commercial banks are also developing their procedure and operational guideline supported by structured recruitment process and subsequent training with a view to mitigating credit risks and other risks for a smooth flow of SME financing. Most businesses in Bangladesh are in need of small short-term loans to help finance their working capital needs or purchase of fixed assets. So when a bank brings about a momentous difference in these peoples lives by meeting their demand, the bank is more than a bank. It's a promise - a promise to rise against all adversities; a promise to quality livelihood; a promise to bridge ordinary people with extraordinary opportunities.SME financing has been identified as a major obstacle to SME growth. Unfortunately, the issue seems to be as unresolved as it always has been. Though the majority of the issues are with the SME themselves, the banks also have major issues in designing financial products for the SMEs. As a developing country Bangladesh has a lot of potentiality in SME sector. Our Study is here to know the SME financing and its problems \& prospect with a suggestions and recommendations regarding the issue.

\section{Objectives of the study}

- To identify the potentiality of SME in the economy in respect of the contribution to Gross Domestic product (GDP).

- To detect the problems of SME financing.

$\vartheta$ To provide necessary recommendations to overcome the problems.

\section{Methodology OF THE StUdY:}

Qualitative data were gathered from the qualitative survey by questioning $100 \mathrm{SME}$ consumers. The research process by Howard and Sharp (1983) was followed for this research which could be summarized as follows:

- Formation of research question.

- Reviewing of secondary data.

- Decide research approach.

- Collect information.

- Analyse data.

- Present findings.

\section{LITERATURE REVIEW}

Under Bangladesh bank regulation state-owned commercial banks and private owned commercial banks are the target of SME loan disbursement. $40 \%$ of total loans are reserved for the small entrepreneurs because it is treated as core media of reducing unemployment. The solutions rest in a combined set of actions along the lines. In the FSS 
2020 work on SME development it was presented that the Least Developed Countries (LDCs) in the east have started refocusing their attention on SMEs to enhance their role in bringing about structural changes in their economies. (2006) . Dr. Sharif Bhuiyan found like many other countries, informal sector in Bangladesh does not exist in a vacuum. There are clear interconnectedness, partnership and continuity with the formal sector - maintaining a two way flow of labor, goods, finances etc between the two sectors. In Bangladesh rapid transformation of the informal sector may not be possible, feasible and/or sustainable. Policy initiatives to formalize the informal sector should therefore adopt a gradualist approach (2007). Dr Khondaker Golam Moazzem showed that in the Sixth Five Year Plan (6th FYP) acceleration of GDP growth (from 6.1 percent in FY 2010 to 8.0 per cent in FY2015) has been targeted through excelling the performance of industrial sector, particularly of the manufacturing sector. The growth of the manufacturing sector will have to be attained through improvement of existing enterprises and also by creating new ones. However, an overwhelming number of these enterprises are micro (having less than 10 workers), small (10-49 workers) and medium (50-99 workers) enterprises, usually called MSMEs/SMEs (2008). S. M. Akterujjaman came into a conclusion that SMEs are a fundamental part of the economic fabric in developing countries, and they play a crucial role in furthering growth, innovation and prosperity. Unfortunately, they are strongly restricted in accessing the capital that they require to grow and expand, with nearly half of SMEs in developing countries rating access to finance as a major constraint (2010). S. M. Nasrul quadir and DR. Mohammad Saleh Jahur argued that SMEs of Bangladesh have been vulnerable to frequent policy changes of Government from time to time. Besides, they are facing severe competition in and outside the country. As a result, the profitability of SMEs has got squeezed and many of them have got financially distressed. Besides, Entrepreneurs of SMEs (2011). Iftikhar Hussain, Zeeshan Farooq and Waheed Akhtar opined that Across the South Asia, the contribution of SMEs to the overall economic growth and the GDP is high. It is estimated that SMEs contribute $50 \%$ of Bangladesh's industrial GDP and provide employment to $82 \%$ of the total industrial sector employment. In Nepal, SMEs constitute more than $98 \%$ of all establishments and contribute $63 \%$ of the value-added segment. In India, SMEs' contribution to GDP is $30 \%$.( 2012).

\section{Definition of Small EnTERPRise}

Enterprise may be segmented based on its capital investment, size, and production volume and so on. Egypt defines SMEs as having more than 5 and fewer than 50 employees, Vietnam considers SMEs to have between 10 and 300 employees. The World Bank defines SMEs as those enterprises with a maximum of 300 employees, \$15 million in annual revenue, and $\$ 15$ million in assets. The Inter-American Development Bank, meanwhile, describes
SMEs as having a maximum of 100 employees and less than $\$ 3$ million in revenue.

Under European Union definition: 'The category of micro, small and medium-sized enterprises is made up of enterprises which employ fewer than 250 persons and which have an annual turnover not exceeding 50 million euro, and/or an annual balance sheet total not exceeding 43 million euro.' Small and medium enterprises are thus defined as firms with 10 to 250 employees, and more than 10 million euro turnover or annual balance sheet total.

Under Bangladesh Bank's regulations Small Enterprise refers to the firm/business which is not a public limited company and complies the following criteria:

\begin{tabular}{|c|c|c|c|}
\hline $\begin{array}{c}\text { Serial } \\
\text { No. }\end{array}$ & Sector & $\begin{array}{c}\text { Fixed Asset other than } \\
\text { Land and Building (Tk.) }\end{array}$ & $\begin{array}{c}\text { Employed } \\
\text { Manpower } \\
\text { (not above) }\end{array}$ \\
\hline 01. & Services & $50,000-50,00,000$ & 25 \\
\hline 02. & Business & $50,000-50,00,000$ & 25 \\
\hline 03. & Industrial & $50,000-1,50,00,000$ & 50 \\
\hline
\end{tabular}

Source: Bangladesh Bank

Definition of Medium Enterprise:

Medium Enterprise refers to the establishment/firm which is not a public limited company and complies the following criteria:

\begin{tabular}{|l|l|l|l|}
\hline $\begin{array}{l}\text { Serial } \\
\text { No. }\end{array}$ & Sector & $\begin{array}{l}\text { Fixed Asset other than } \\
\text { Land and Building } \\
\text { (Tk.) }\end{array}$ & $\begin{array}{l}\text { Employed } \\
\text { Manpower } \\
\text { (not above) }\end{array}$ \\
\hline 01. & Services & $50,00,000-10,00,00,000$ & 50 \\
\hline 02. & Business & $50,00,000-10,00,00,000$ & 50 \\
\hline 03. & Industrial & $1,50,00,000-20,00,00,000$ & 150 \\
\hline
\end{tabular}

Source: Bangladesh Bank

\section{SCOPES OF SMES}

The structural arrangements of Bangladesh's industries show that jute, textiles, paper, steel and engineering, cement, chemical, fertilizer and pharmaceutical industries are under the big and medium scale industries. On the other hand, specialized textile industries (including garments), backward linkage industries, hand-operated welding, food processing and food linkage industries, leather, ceramics, light engineering including automobiles, basic metal engineering, small scale chemical engineering, rubber industries, paper printing and publishing industries, small fabrication industries, non-metal mineral products, batteries, electrical, electronics, handicrafts, agro-based industries, multilateral jute goods, silk industries, fruit processing, poultry farming, fisheries, teagardening and processing, vegetable seed farming, floriculture and agro-forestry, and printing industries, ginning and baling, construction industries, transportation (including automobiles), cinema and photography, pathological laboratories, cold storage, furniture, computer indus- 
tries, fast food, frozen food, etc, under service industries, and many other sectors are included in the SMEs. But there are 11 booster sectors of SMEs in the Industrial Policy 2005 which are Electronics and Electrical, Software Development, Light Engineering and Metal Works, Agroprocessing/Agri-business/plantation agriculture/specialist farming/tissue-culture and related business, leather-making and leather goods, Knitwear and ready-made garments, Plastics and other synthetics, Healthcare and diagnostics, Pharmaceuticals/Cosmetics/Toiletries and Fashion-rich personal effects, wear and consumption goods.

\section{IMPORTANCE OF SMES}

It is said internationally that Small and medium Enterprises (SMEs) account for about 50 percent of GDP and 60 percent of employment. SMEs are estimated to contribute between 25 and 35 percent of world manufactured exports. In terms of industrialization, Japan drew special attention to the professionals and policymakers in the international arena. Statistics show that Japan has achieved its industrial development heavily based on SMEs. Some of the world's best performing economies, notably Taiwan and Hong Kong, are heavily based on small enterprises. In much of the developing world, the private sector economy almost entirely comprises of SMEs. Contribution of SMEs in some selected countries shows that it has provided very significant proportion of GDP and employment in their national economy.

\begin{tabular}{|l|l|l|l|}
\hline Country & $\begin{array}{l}\text { SMEs as } \\
\% \text { of all } \\
\text { Enterprises }\end{array}$ & $\begin{array}{l}\text { Contribution } \\
\text { of SMEs to } \\
\text { GDP (\%) }\end{array}$ & $\begin{array}{l}\text { Contribution } \\
\text { of SMEs to } \\
\text { employment }\end{array}$ \\
\hline Bangladesh & 80.00 & $20-25$ & 40.00 \\
\hline India & 97.60 & 80.00 & - \\
\hline Pakistan & 60.00 & 15.00 & 80.00 \\
\hline China & 99.00 & 60.00 & 92.00 \\
\hline Japan & 99.7 & 69.50 & 72.0 \\
\hline Hon Kong & - & - & 61.50 \\
\hline
\end{tabular}

Entrepreneurs form Hong Kong, Japan and Korea have taken advantage of Bangladesh's cheap and easily trainable labour and its infrastructure facilities to manufacture products for the export market.

The Industrial Revolution of 1760-1850 represents a good testimony of the inherent innovative spirit of SMEs, which are increasingly challenged in the present century particularly after winds of economic change cum technological innovations and industrial liberalization, have swept various economies of the world. These challenges notwithstanding, SMEs have remained as much important and relevant economic catalysts in industrialized countries as they are in the developing world. In many developed countries, more than $90 \%$ of all enterprises are within the SME sub-sector while $80 \%$ of the total industrial labor force in Japan, $50 \%$ in Germany and $46 \%$ in USA small businesses contribute nearly $39 \%$ of the country's national income. Comparable figures in many other developed countries are even higher.

In many developing countries including Bangladesh, manpower is relatively abundant. It is, therefore, imperative that their full and effective utilization should become a focal point of socio-economic policies. Emphasis has to be laid on SME sector to absorb the surplus manpower in these countries. In fact, developing of SME sector has been requires less capital outlay and at the same time it provides more employment than the large-scale sector. Second, a SME unit does not require highly sophisticated technology. It can, therefore, be useful in backward areas where the people have yet to be trained to meet the challenge of sophisticate technology.

Bangladesh is highly resourceful with so many seasonal fruits and also lots of agricultural products. Pineapple and mango are best used to produce jam/jelly/juice etc under SME. Tomato sauce and potato chips are popularly used all over the world. SME is most suited for processing the items. If we can add more quality to the products and ensure proper marketing, tremendous demand will be created in domestic and export market. In RMG industries (knit) circular machines are used for knitting of the items. The circular machines can also be set at household level to perform job works to feed RMG industries for ultimate export of T/Polo Shirts etc. This is a subcontracting system where RMG industries supply yarns to the entrepreneurs having circular machines. The system has already been introduced in Dhaka and Narayangonj areas with growing demand. Shoe making by small industries as job works of big shoe companies like BATA is a glaring example of SME product. BATA supplies raw materials to lots of small factories at household level in Dhaka city and gets the product (shoes) completed through subcontract system. SMEs are a fundamental part of the economic fabric in developing countries like Bangladesh, and they play a crucial role in furthering growth, innovation and prosperity.

Small and medium enterprises (SMEs) play a major role in economic development in every country, including in African countries. Studies indicate that in both advanced economies and developing countries SMEs contribute on average 60 percent of total formal employment in the manufacturing sector (Ayyagari et al, 2007). For African economies, the contribution of the SME sector to job opportunities is even more important. Taking into account the contribution of the informal sector, SMEs account for about three-quarters of total employment in manufacturing (Ayyagari et al, 2007).

\section{FINDINGS AND THEIR ANALYSIS}

The questionnaire survey covered 100 major small and medium enterprise businesses that are from Trading \& Traders, Agro Processing Products Import \& Export, Wood \& Steel Furniture, Sea Services Company, Importer Exporter 
\& Commercial Agent in International Market, General \& Merchant Commission Agent. This is shown in Table 7.1.

Table 7.1 SME Subsectors

\begin{tabular}{|l|l|l|l|}
\hline SME Subsectors & No & Percent & Cumulative \\
\hline Trading \& Traders. & 30 & $30 \%$ & $30 \%$ \\
\hline $\begin{array}{l}\text { Agro Processing Products Im- } \\
\text { port \& Export. }\end{array}$ & 10 & $10 \%$ & $40 \%$ \\
\hline Wood \& Steel Furniture. & 20 & $20 \%$ & $60 \%$ \\
\hline Sea Services Company. & 10 & $10 \%$ & $70 \%$ \\
\hline $\begin{array}{l}\text { Importer Exporter \& Commer- } \\
\text { cial Agent in International Mar- } \\
\text { ket. }\end{array}$ & $20 \%$ & $90 \%$ \\
\hline $\begin{array}{l}\text { General \& Merchant Commis- } \\
\text { sion Agent }\end{array}$ & 10 & $10 \%$ & $100 \%$ \\
\hline Total . & 100 & $100 \%$ & \\
\hline
\end{tabular}

Source: Field survey

Table 7.2 Characteristics of sample SMEs by ownership pattern

\begin{tabular}{|l|l|l|l|}
\hline & No & Percent & Cumulative \\
\hline Sole Proprietorship & 70 & $70 \%$ & $70 \%$ \\
\hline Partnership & 30 & $30 \%$ & $100 \%$ \\
\hline Private Limited Company & 00 & $00 \%$ & \\
\hline Public Limited Company & 00 & $00 \%$ & \\
\hline Total & 10 & $100 \%$ & \\
\hline
\end{tabular}

Source: Field survey

Table 7.2 shows that our sample survey collected data from four types of SMEs. Nearly $70 \%$ of them are registered under sole proprietorship act, $30 \%$ are under partnership act. Majority of the small entrepreneurs are either registered as the sole proprietorship or under Partnership Company.

Table 7.3 Initial fixed investment in the SMEs

\begin{tabular}{|l|l|l|}
\hline Investment & Number & Percent \\
\hline Below Tk 300000 & 30 & $30 \%$ \\
\hline Between Tk 300000 to Tk 1 Crore & 70 & $70 \%$ \\
\hline Between Tk 1 Crore to Tk 10 Crore & 00 & $00 \%$ \\
\hline Between Tk 10 Crore to Tk 25 Crore & 00 & $00 \%$ \\
\hline Total & 100 & $100 \%$ \\
\hline
\end{tabular}

Source: Field survey

Table 7.3 shows that 30 percent of the SMEs surveyed had initial investment of below Taka 300,000. Other 70 percent were with initial investment between Taka 300,000 and $1,00,00,000$. Table 5.3 shows the distribution of sample SMEs with their initial fixed Investments.

Table 7.4 Markets in which SMEs sell their product

\begin{tabular}{|l|l|}
\hline SMEs Selling to & $\%$ of Responses \\
\hline Retail Market & $40 \%$ \\
\hline Niche Market & $10 \%$ \\
\hline Industrial Market & $20 \%$ \\
\hline International Market & $30 \%$ \\
\hline Total Responses & $100 \%$ \\
\hline
\end{tabular}

Source: Field survey

Copyright (C) 2013, Asian Business Consortium | ABR
Table 7.4 shows that nearly 40 percent sells in the retail market, 10 percent sells to niche markets, 20 percent sells to industries, and 30 percent sells to foreign markets. Clearly, the linkage between the large industries and the SMEs is the weakest of all according to our findings. Moreover, some said that they will be interested to find new markets abroad to sell their products.

Table 7.5 Full time employees in SMEs

\begin{tabular}{|l|l|}
\hline Number of full time employees & Percentage \\
\hline Less than 25 & $60 \%$ \\
\hline 25 to 49 & $30 \%$ \\
\hline 50 to 74 & $10 \%$ \\
\hline 75 to 99 & $00 \%$ \\
\hline 100 or above & $00 \%$ \\
\hline Total: & $100 \%$ \\
\hline
\end{tabular}

\section{Source: Field survey}

Table 7.5 shows that nearly 60 percent of them employs less than 25 full time employees per firm, while the next largest group consists of 30 percent of the SMEs employed between 25-49 and the rest employ between 50-74 persons.

Table 7.6 Reasons for taking credits by SMEs

\begin{tabular}{|l|l|}
\hline Reasons for seeking credits & $\begin{array}{l}\% \text { of Re- } \\
\text { spondents }\end{array}$ \\
\hline To start the business. & $20 \%$ \\
\hline To rent/lease premises & $00 \%$ \\
\hline To procure equipment from local markets & $20 \%$ \\
\hline $\begin{array}{l}\text { To procure equipment from international } \\
\text { markets }\end{array}$ & $10 \%$ \\
\hline To procure raw material from local markets & $10 \%$ \\
\hline To facilitate works in process & $30 \%$ \\
\hline To build inventory & $00 \%$ \\
\hline To hire skilled labour & $10 \%$ \\
\hline To ensure quality control/ISO certificate & $00 \%$ \\
\hline To finance equity share & $00 \%$ \\
\hline Total & $100 \%$ \\
\hline
\end{tabular}

Source: Field survey

Table 7.6 Survey results show that there are at least ten reasons for which SMEs seek loans from financial institutions. The first reason is to initiate the business. Nearly 20 percent of the SMEs took credit to start their business. Nearly 20 percent clients seek loans to procure equipment from local markets.10 percent are for to procure equipments from international market and 30 percent are for to facilitate work in process.

Table 7.7 How long SMEs need the loan

\begin{tabular}{|l|l|}
\hline How long SMEs need the loan & $\%$ of Respondents \\
\hline 1 year & $30 \%$ \\
\hline 2 year & $70 \%$ \\
\hline $3-4$ year & $00 \%$ \\
\hline More than 4 years & $00 \%$ \\
\hline Total & $100 \%$ \\
\hline
\end{tabular}

Source: Field survey

Table 7.7 shows that for how many years these SMEs 112 | P a g e 
needed the loan? Survey results show that most of them needed the finance for a period of 2 years. The period of time (the average) shows in details in table 7.7.

Table 7.8 Interest charges on loan to SMEs

\begin{tabular}{|l|l|}
\hline Interest charges on loan to SMEs & $\%$ of Respondents \\
\hline $13 \%$ & $10 \%$ \\
\hline $13.50 \%$ & $30 \%$ \\
\hline $14 \%$ & $50 \%$ \\
\hline $14.50 \%$ & $10 \%$ \\
\hline Total & $100 \%$ \\
\hline
\end{tabular}

Source: Field survey

Table 7.8 Survey results show that most of the SMEs got the loan at an interest rate of $14 \%$

Table 7.9 Preferred source of taking loans.

Preferred source of taking loans $\%$ of Respondents

$\begin{array}{ll}\text { Private Commercial Banks } & 80 \%\end{array}$

\begin{tabular}{|l|l}
\hline Foreign Direct Investment & $00 \%$ \\
\hline
\end{tabular}

Nationalized Commercial Banks $20 \%$

\begin{tabular}{l|l}
\hline Total $100 \%$ \\
\hline
\end{tabular}

Source: Field survey

Table 7.9 shows that most of the SMEs got their finance from private commercial banks ( 80 percent).Besides SMEs used retained earnings to finance their activities. However, in terms of the preferred source of taking credit or get finances, SMEs stated that Private commercial banks are their most favored sources of finance. Their next choice is the nationalized commercial banks. Nearly 20 percent preferred Nationalized Commercial Banks and reinvestment of profits.

Table 7.10 Waiting period between loan application \& sanction

\begin{tabular}{|l|l|}
\hline $\begin{array}{l}\text { Period between loan application \& } \\
\text { sanctions }\end{array}$ & $\%$ of Respondents \\
\hline $2-3$ Month & $60 \%$ \\
\hline 3-4 Month & $40 \%$ \\
\hline $4-5$ Month & $00 \%$ \\
\hline 5 Month or more & $00 \%$ \\
\hline Total & $100 \%$ \\
\hline
\end{tabular}

Source: Field survey

Table 7.10 shows that on average it took 2-3 months for an SME to get their loan money for starting the business. If they were to get a loan for rental/leasing of premises, the waiting period increased to 3-4 months. However, we found in some cases it needs more time to sanction a loan by SMEs.

Table 7.11 Why institutional sources fail to provide SME loans

Reasons for what institutional $\%$ of Respondents sources fail to provide SME loans

High interest rate $60 \%$

Too much paper work $20 \%$

Lack of proper contact with SME $00 \%$

Copyright (C) 2013, Asian Business Consortium | ABR

\begin{tabular}{|l|l|}
\hline clients & \\
\hline Collateral requirements & $20 \%$ \\
\hline Total & $100 \%$ \\
\hline
\end{tabular}

\section{Source: Field survey}

Table 7.11 shows that most of the institutional sources fail to provide SME loans due to high interest rate, approximately $60 \%$ SME loan holders response about that but some also think that too much paper work is also responsible for failure.

Table 7.12 Why SME clients are more dependent with BASIC, BSRS, BSB, RAKUB etc

\begin{tabular}{|l|l|}
\hline & $\%$ of Respondents \\
\hline For high esteem security & $00 \%$ \\
\hline Low interest rate & $80 \%$ \\
\hline Government institution & $20 \%$ \\
\hline Total & $100 \%$ \\
\hline
\end{tabular}

Table 7.12 shows that most of the SME clients are more dependent for loan to BASIC, BSRS , BSB,RAKUB etc due to low interest rate than other private commercial banks or nationalized commercial banks

Table 7.13 How do the SME entrepreneurs get loans from banks?

\begin{tabular}{|l|l|}
\hline & $\%$ of Respondents \\
\hline Credit approval against the bank & $100 \%$ \\
\hline $\begin{array}{l}\text { Fixed deposit against the loans } \\
\text { Fulfilling adequate collateral re- } \\
\text { quirements }\end{array}$ & $00 \%$ \\
\hline Total & $100 \%$ \\
\hline
\end{tabular}

Source: Field survey

Table 7.13 shows that almost all of the SME entrepreneurs get loans from banks via credit approval against the bank. Some clients get loans via fixed deposit against the loans but it provides less amount what they applied for.

Table 7.14 Where are the credits used

\begin{tabular}{|l|l|}
\hline & $\%$ of Respondents \\
\hline Meeting salary \& daily expenses & $00 \%$ \\
\hline Purchase of raw materials & $60 \%$ \\
\hline To pay their creditors & $20 \%$ \\
\hline Over draft facilities & $20 \%$ \\
\hline Total & $100 \%$ \\
\hline
\end{tabular}

Source: Field survey

Table 7.14 shows that $60 \%$ entrepreneurs used the credit to purchase raw materials and $20 \%$ used it to pay their creditors and the rest are for enjoying overdraft facilities.

Table 7.15 What are the obstacles faced by the SMEs in getting loans

\begin{tabular}{|l|l|}
\hline & $\%$ of Respondents \\
\hline Lack of collateral assets & $20 \%$ \\
\hline High interest on govt. bonds & $20 \%$ \\
\hline Lack of ability to draw business plan & $20 \%$ \\
\hline $\begin{array}{l}\text { High rate of non performance loans in } \\
\text { banking sector }\end{array}$ & $10 \%$ \\
\hline
\end{tabular}




\begin{tabular}{|l|l|}
\hline Lack of long term relationship & $30 \%$ \\
\hline Total & $100 \%$ \\
\hline
\end{tabular}

Source: Field survey

Table 7.15 shows that the main obstacles faced by the SMEs in getting loans due to lack of long term relationship with the financial Institutions,almost 30\% client think about that and the rest obstacles are lack of collateral asset, High interest on government bonds, Lack of ability to draw business plan, High rate of nonperforming loans in banking sector.

Table 7.16 The major impediments in the banking sector that have serious ramification on SMEs access to finance

\begin{tabular}{|l|l|}
\hline & $\%$ of Respondents \\
\hline Too much paper work & $30 \%$ \\
\hline $\begin{array}{l}\text { Good communication with pro- } \\
\text { spective clients }\end{array}$ & $10 \%$ \\
\hline Hazardous in lengthy process & $50 \%$ \\
\hline Institutional barriers & $10 \%$ \\
\hline Total & $100 \%$ \\
\hline
\end{tabular}

Source: Field survey

Table 7.16 shows that The major impediments in the banking sector that have serious ramification on SMEs access to finance is the Hazardous in lengthy process.50 percent clients are not interested to go in a lengthy process. $30 \%$ clients think too much paper work is also a major impediments.

Table 7.17 Is restructuring of the Credit Information Bureau (CIB) with resources a must to help SMEs and financial institutions for SMEs finance and development?

\begin{tabular}{|l|l|}
\hline & $\%$ of Respondents \\
\hline Yes & $100 \%$ \\
\hline No & $00 \%$ \\
\hline Total & $100 \%$ \\
\hline
\end{tabular}

Source: Field survey

Table 7.17 shows that all of the SME entrepreneurs agree to restructure the CIB to get information regarding credit history, bank and firm's performances etc and to help SMEs and financial institutions for SMEs finance and development.

Table 7.18 Does government or the private institutions can play a better role so that the outcomes from the interactions between players from both sides are maximized?

\begin{tabular}{|l|l|}
\hline Need a public private partnership & $\%$ of Respondents \\
\hline $\begin{array}{l}\text { Govt. should provide mortgage } \\
\text { free loan up to a limit }\end{array}$ & $60 \%$ \\
\hline $\begin{array}{l}\text { Should set up an special fund by } \\
\text { the Govt. }\end{array}$ & $20 \%$ \\
\hline Developing skilled manpower & $10 \%$ \\
\hline Total & $100 \%$ \\
\hline
\end{tabular}

Source: Field survey

Table 7.18 shows that $60 \%$ SME entrepreneurs think that government should provide mortgage free loan up to a limit to the major SME entrepreneurs.20\% responses that it is necessary to set up an special fund by the government to support the entrepreneurs when they are in crisis.

\section{SUMMARY OF FINDINGS}

Most of the SMEs are found to have borrowed fund for their initial setup and for procurement of raw materials. At the same time, it has been found that the initial waiting period for getting fund for these activities is the highest 34 months (average). This remains as a major obstacle for the SMEs .Most have supported the view that government should participate in these activities by setting up special funds for this. Considering these, a governmentsponsored fund to help SMEs to set up initial business would help the sector. Such endeavor is not uncommon in other countries that we have studied

In the survey, it was found that $20 \%$ mentioned that collateral requirement is a major obstacle to secure loans for them. On the top of this, 30 percent has mentioned about the long and tedious paperwork required for processing of loans as a major obstacle. Considering these, providing a state guarantee for credit to genuine small and medium entrepreneurs was considered as an option for SMEs with good standing. Most of the SME entrepreneurs supported the view that government should provide mortgage and guarantee free loan up to a certain limit. Such practice is not uncommon in other countries.

More than 20 percent of the small and medium entrepreneurs were found to have no training in terms of preparing a sound business plan for taking credits. Under the circumstances, the risk of running business increases. Investors responded favored the idea of developing a financial incentive schemes based on ranking of sound business plan. Such practice would help the sector to mature using sound business plan and through training. We can observe from the following that Japan, USA has also used such schemes to promote sound business record keeping in the SMEs.

Based on the results of the survey, entrepreneurs support an institutional network under private-public partnership to accumulate and redistribute funds for SMEs financing. Of them, most believe restructuring of the public and private support institutions are necessary for the policy to be effective.

Most of the SMEs responded positively of the above policy recommendation based on the questionnaire survey.

The survey result shows that most of the SMEs support venture capital formation through SMEs financing.

Most of the entrepreneurs suggested HRD and training programs for entrepreneurs through government initiatives.

Maximum entrepreneurs want the government to help government agencies and financial institutions in development of skilled manpower to deal with SMEs more efficiently and effectively. 
In the survey, around $80 \%$ of the entrepreneurs prefer Chamber of Commerce and Industries to take leadership in training and education of the entrepreneurs. Technical institutions, Universities, and NGOs are the next in line of preferences for potential training institutions.

In the survey,100 percent of the investors feel that lack of special client relationships with the management of the financial institutions and lack of knowledge about the customer and the bank are one the five key factors why SMEs finding it hard to get loans from financial institutions.

In the survey, though on average most of the loan is taken from financial institutions like BASIC, RAKUB and other support services from private institutions, most of the investors expressed the view of getting more financial support from institutions that would exclusively deal with SMEs.

\section{ReCOMmendations}

Special SME Development Fund: Government should set up special funds to raise the required equity capital for SMEs with the potential entrepreneurs.

Credit Guarantee Scheme: Government should provide mortgage and guarantee free loan up to a certain limit under the credit guarantee scheme.

Financial Incentive Scheme: Government should develop financial incentive schemes for SMEs through a ranking system for their sound business plan and feasibility study.

Institutional Network: Development should be done on institutional network through public-private support partnership would be more effective in SMEs financing by pooling the unused or surplus funds available around the country. To make it viable, restructuring of the existing public agencies as well as private support institutions are required.

Alternative Credit Scheme: As an alternative to collateral based financing, loan should be provided to potential SMEs based on previous years cash flow statements (i.e., like project financing).

Venture Capital: Venture capital formation for SME financing should be highly encouraged through enforcement of proper rules and regulations by the Stock Exchange Commission (SEC) and other key players including the Bangladesh and private support organizations.

Bank Syndication Scheme: Forming bank syndication between micro finance institutions and commercial banks for SMEs financing. Micro finance institutions should provide recommendation and credit history to commercial banks for SME development.

HRD in Financial institutions and in Government offices: Government should provide Human Resource development and training program for financial institution employees and related government officials to smooth out the SMEs financing process.

Training and Development: Relevant associations of Chamber of Commerce and Industries should take the leadership role in promoting SMEs training and development.

Sub-contracting arrangements: Government should come up with policies in collaboration with private support organizations to link up SMEs and suppliers of manufacturers and raw materials under the same industry (both backward and forward linkage service providing firms) based on subcontracting / outsourcing agreement. If developed and implemented accordingly, this types of cooperatives would lead to higher value addition and economies of scale.

Government, associations of Chambers of Commerce and Industry, credit information bureau (CIB), Bangladesh Bank and Stock Exchange Commission (SEC) and renowned auditing firms should jointly prepare a reliable database, where necessary information about the existing and potential entrepreneurs and formal creditors will be available. The date base will be accessible only to the concerned authorities. This would ensure transparency and accountability while choosing the right entrepreneur and the right project among the pool of applicants.

Specialized Financial Institution: There should be created a separate financial institution to deal exclusively regarding SME financing and promotion of their goods and services, both in domestic and foreign market.

Credit rating system: Alternative to existing financial tools and leasing, the "downgrading" of banks to preferred target groups, especially SMEs and "upgrading" of successful non- governmental organizations (NGOs) and private support organizations could help to provide finance to Microenterprises and SMEs. Such approaches can eliminate the need for credit guarantees.

\section{Conclusion}

It is interesting to observe that the conditions for small industry development that we find today, being at the threshold of total globalization, are very much the same as observed several-decades ago. In spite of the criticism and neglect of the SME sector on the grounds of inefficiency and non-optimal use of productive factors compared to larger industries, SMEs are beginning to be extolled for their greater dependence on labor-intensive production techniques, lower requirements of imported inputs and better geographical dispersion. In both developed and under developed economies commercial banks play a very useful and dynamic role. Capital is the main factor of modern production and entrepreneurs are helpless without adequate funds. Banks should help them and mobilize the capital of the country for productive purposes responsible for economic development and government also 
should come forward to patronize the entrepreneurs.

\section{REFERENCES}

Abdul Awal Mintoo, SMEs in Bangladesh, CACCI Journal, Vol. 1, 2006.

Akizawa, Hikari., \& Kijima, Kyoichi, Kijima. Theory \& Research: Internet-based Entrepreneurial Networking to Evolve the Japanese Industrial Structure. Department of Value and Decision Science, Tokyo Institute of Technology, Japan.

Amit Bouri ,Mark Breij ,Magatte Diop ,Randall Kempner ,Bailey Klinger ,Keely Stevenson ,Report on Support to SMEs in Developing Countries through Financial Intermediaries, Dalberg, November, 2011.

Berman, J.A., Gordon, D.D. and Sussmann, G. (1997) 'A study to determine the benefits small business firms derive from sophisticated planning versus less sophisticated types of planning', Journal of Business and Economic Studies, 3(3): 1-11.

Bitila Shosha,SME Challenges in Albania, International Review of Business and Social Sciences Vol. 1, No. 40-48

Bracker, J.S., Keats, B.W. and Pearson, J.N. (1988) 'Planning and financial performance among small firms in a growth industry', Strategic Management Journal, 9: 591-603.

Dahi Emine ,PhD Scholar, Financial Challenges That Impede Increasing the Productivity of SMEs in Arab Region, School of Management, Shanghai University

Dr Khondaker Golam Moazzem, Micro, Small and Medium Enterprises in Bangladesh: Are They Scaling Up?

Dr. Mrs Ann Ogbo and Agu Chidiebere Nwachukwu, The Role of Entrepreneurship in Economic Development: The Nigerian Perspective, European Journal of Business and Management, ISSN 2222-1905 (Paper) ISSN 2222-2839 (Online), Vol 4, No.8, 2012

FSS 2020 International Conference "SME Issues, Challenges and Prospects" Peter Mousley, Finance and Private Sector Department, Africa Region, World Bank

Iftikhar Hussain, Zeeshan Farooq and Waheed Akhtar, SMEs development and failure avoidance in developing countries through public private partnership. 1 February, 2012 African Journal of Business Management Vol. 6 (4), pp. 1581-1589, www.academicjournals.org/AJBM,ISSN 1993-8233 @2012 Academic Journals

Milken Institute, Stimulating Investment in Emerging-Market SMEs, October 2009 , European Commission-2003,( Extract of Article 2 of the Annex of Recommendation 2003/361/EC)

S. M. Akterujjaman, "Problems and Prospects of SMEs Loan Management": A Study on Mercantile Bank Limited, Khulna Branch Volume- V, Issue- 02, July-December, 2010.

S. M. Nasrul Quadir and Dr. Mohammad Saleh Jahur, Determinants of Success and Failure of Entrepreneurs of SMEs in BangladeshAn Explorative Study , European Journal of Business and Management, ISSN 2222-1905 (Paper) ISSN 2222-2839 (Online) .

Sharif Bhuiyan, Legal machanism Empower Informal BusinessBangladesh, The National Consultation Conference organized by Dr. Shahdeen Malik and BRAC University, 21 January 2007 Victor M. Chando and Sofiane Sekioua, Bank Financing to Small and Medium Enterprises in East Africa: Findings of a Survey in Kenya, Tanzania, Uganda and Zambia, Pietro Calice, Working Paper No. 146, March 2012

\section{Appendix Questionnaire}

1. What type of businesses should be included under SME sector?

2. What can be the ownership pattern under small and medium enterprises whether it may be sole proprietorship. Partnership, private limited or public limited?

3. What will be the initial investment under SME?

4. In which markets SMEs will sell their products? It may be Retail market, Niche market, Industrial market or International market?

5. What is the number of full time employees in SMEs?

6. What are the reasons for which SMEs seek loans from financial institutions?

7. For how long SMEs need the loan?

8. What are the interest charges of SME loans?

9. Which is the preferred source of taking credit or get finances: - private commercial banks, foreign direct investment or nationalized commercial bank?

10. Terms of the time lapse between initial application for the loan and its ultimate Delivery?

11. Why institutional sources fail to provide SME loans?

12. Why do most of the SME entrepreneurs choose BASIC, BSRS, BSB, RAKUB, etc.?

13. How do the SME entrepreneurs get loans from Banks?

14. Where are the credits used?

15. What is the main obstacle faced by the SMEs in getting loan from financial institutions?

16. What are the main reasons behind the difficulty the SMEs face in getting loans with low interest rate from financial institutions?

17. What are the major impediments in the banking sector that have serious ramification on SMEs access to finance?

18. Is restructuring of the Credit Information Bureau ("CIB") with resources a must to help SMEs and financial institutions to get information regarding credit history, bank and firm's performances etc., for SMEs finance and development?

19. Does government or the private institutions can play a better role in providing human resource development and training for entrepreneurs and employees of the financial institutions so that the outcomes from the interactions between players from both sides are maximized? 